\title{
International Terrorism and Global Response: An Appraisal
}

\author{
Chris. O. Opukri ${ }^{1}$ and Kimiebi Imomotimi Ebienfa ${ }^{2}$ \\ ${ }^{I}$ Department of Political Science, Niger Delta University, Nigeria \\ ${ }^{2}$ Department of Political Science, University of Ibadan, Nigeria
}

\begin{abstract}
International Terrorism as it appears is the scourge of all nations in the globe. There is no particular nation that is shielded from its effects either in terms of a germane threat or outright infliction of destruction. The responses from the said menace have led to what is currently termed as "the war on terror", an approach that creates collateral damages of its own. This paper in the first instance, has examined the concept "war on terror" and its legal justifications and ramifications. While the military can engage in fighting wars, it is not quite correct to christen some conflicts as war on terror because we cannot conquer terror through war. War on terror can only lead to destruction of property and human suffering and cannot usher peace and stability. Finally, the authors are of the view that arbitrations, negotiations, diplomatic sanctions and economic embargo, could serve as a better option for peace and security than military expeditions.
\end{abstract}

Key Words: Terrorism, war on terror, international law, sanctions, bombings

\section{Introduction}

Terrorism has been an old scourge to human kind from time, and for the past three decades, terrorist activities in the world have increased to an alarming rate. For instance, since the 1970s, international terrorism sponsored by states and non-state actors, has evolved into an insidious trend that often hurt civilian populations. Often used by the relatively powerless against the powerful, terrorists operate basically through surprise (Mingst, 1999).

From the bombing of the embassies of the United States of America in Kenya and Tanzania in 1988, to the September 11, 2001 world trade centre bombings in New York, the Mumbai attacks in India, the killing of the American Ambassador in Libya and the Boko Haram attacks in Nigeria, the story remains the same. Terrorist attacks have continued to cause loss of lives and property. According to Kegley (2007), terrorism poses an alarming kind of contemporary violence.

There are different mechanisms and global policies currently in use for fighting terrorism. These ranges from peaceful and diplomatic negotiations, making secret concessions, pacification, the use of economic sanctions and use of military force in some cases. As a result of the growing sophistication of terrorist networks and the havoc such clandestine groups pose to society, the use of military force is becoming a preferred alternative approach in the struggle against terrorism. This of course has continued to elicit responses and criticisms from policy and legal analysts. Most of such criticisms make reference to the prosecution of what is currently termed as the "war on terror" as exemplified in Iraq and Afghanistan. The invasion of Iraq, which led to the death of President Saddam Hussein, and the fight against the Taliban in Afghanistan have led to the death of many combatants and innocent civilians, coupled with the destruction of properties worth billions of dollars.

The question raised by this paper figures around an acceptable standard of fighting terrorism. The military approach now in vogue does not seem to have fully accommodated the provisions of international law and the responsibility of protecting non-combatant civilians and their properties. The greatest problem with the military approach is the dearth of information needed for precise operations.

Where information gap exists or poorly handled, like the Iraq's chemical weapons detection blunder, military operation may lead to collateral damages that could impinge on international law. To address this, the paper has relied mostly on published materials such as books, journals, government publications and references obtained from emergent global occurrences.

\section{Terrorism: An Overview}

Globally, there are several international conventions that define war crimes and acts of violence but there is no universally accepted definition of terrorism. A popular saying describes one man's terrorist as another's freedom fighter. Indeed, the definitional quest has haunted the field of terror studies, leading some authors to call it the search for the "Holy Grail" (Wardlaw, 1989). Some others, in the other hand, conceive the 
definition of terrorism as a "useless endeavour that should be abandoned" (Lacquer, 1999). Most of all, the political use of the term by states to designate varied acts of opposition has further complicated the search for a definition (Toros, 2008). As Kofi Annan (2004) the former SecretaryGeneral of the United Nations pointed out, "there is no internationally agreed definition of what constitutes a terror act. While there is no shortage of treaties prohibiting acts that are associated with terrorism, the lack of agreement on a clear cut and well-articulated definition undermines the normative and moral approach against terrorism (Enodien, 2003). For instance, almost all Arab States oppose any definition of terrorism that prohibits the deliberate targeting of civilians, if such activities take place in an occupied territory (e.g. that defines a Palestinian attack on Isreali civilians) as terrorism. These objections are reflected in the refusal of States such as Syria, Iran, Saudi Arabia, Lebanon, Jordan etcetera to sign most of the 12 anti- terrorism treaties.

Terrorism, described variously as both a tactic and strategy; a crime and a holy duty; depends on whose point of view is being represented. For instance, the United States Department of Defense defines terrorism as "the calculated use of unlawful violence or threat of unlawful violence to inculcate fear; intended to coerce or to intimate government or societies in the pursuit of goals that are generally political, religious or ideological". The identifiable elements from the definition; violence, fear and intimidation, each produce terror on its victims. To the Federal Bureau of investigation, an American Security Outfits, "terrorism is the unlawful use of force and violence against persons or property to intimidate or coerce a government, the civilian population or any segment thereof, in furtherance of political or social abilities"(Tylor, 2009). The United States Department of State in its view, conceives terrorism as a "premeditated politicallymotivated violence perpetrated against a noncombatant target by sub-national groups or clandestine agents, usually intended to influence an audience"(Nicholas, 2008). From the American definitions, rebels, insurgents, paramilitaries, separatists, militants, guerillas, insurrectionists, fundamentalists etcetera are categorized as terrorists, because they all in one form or the other employ calculated use of unlawful violence to inculcate fear in the pursuit of their goals.

The Anti-Terrorist Act of Uganda (2002) defines terrorism as: the use of violence, economic and cultural or social ends in an unlawful manner. This includes the use of violence or threat of violence to put the public to fear (Mukwaya, 2004). However, the United Nations in 1992 described terrorism as "an anxiety - inspiring method of repeated violent action, employed by semiclandestine individual groups or state actors, for idiosyncratic criminal or political reasons, whereby - in contrast to assassination; the direct target of violence may not be the main target" (Eze, 2003). Terrorism also refers to a deliberate commission of an act of violence to create an emotional response from the victim in the furtherance of political and social goals (Downes, 2008).

On the contrary, the Convention of the Organization of Islamic Conference on combating International terrorism held in 1999, defined terrorism as any act of violence or threat thereof, notwithstanding its motive or intentions, perpetrated to carry out an individual or collective criminal plan with the aim of terrorizing the lives, honor, freedoms, security or rights or exposing the environment or any facility or private or public property to hazards or occupying or seizing them (Reisner, 2002).

In Article 2, of the same regional convention, the Conference of Islamic States posits that, peoples struggle, including armed struggle against foreign occupation, aggression, colonialism, hegemony, aimed at liberation in accordance with the principles of international law, shall not be considered a terrorist crime (Wedgwood and Kenneth, 2009). A crystallization of the above scenario, shows that by the conception of the Islamic world on terrorism, in this view the attack on the World Trade Centre by Al Qaeda, conceived as an attack on hegemony, and the attacks on Israel by the Palestinian or Lebanese groups seen as a fight against occupation or aggression, cannot serve as instances of terrorist attacks.

\section{Terrorism: Cause and Effect}

It has been observed that part of the difficulty in constructing a universally accepted definition of terrorism is a consequence of the existence of organizations and leaders that were formally branded as terrorist but eventually evolved into acceptable leaders governments. This is the case with some liberation movements that fought colonialism or is still fighting oppressive regimes within their own countries as a last resort. An example of this is Jomo Kenyatta's (Mau Mau) and Nelson Mandela's Africa National Congress. Interestingly, Mandela (Africa's Foremost Nationalist Leader) wrote in his autobiography that "50 years of non-violence brought his people nothing, but more repressive legislation and fewer rights". The United States Terror watch list of suspects, discovered in 2008 from FBI compilations included Mandela's name as a terrorist suspect.

Be that as it may, what we discovered from the above definitions and interpretations of terrorism are three key elements that appear in most definitions. They are (1) a violence means, (2) aimed at triggering political change, (3) by affecting a larger audience than its immediate target. 
International terrorism, which is terrorism that transcends national borders, is therefore both an action and reaction to repression, desperation and hopeless situations. The actions and reactions take on political, economic, social, ideological, psychological, emotional and religious fervor (Mukwaya 2004). Terrorism is therefore a politically, economically and religiously motivated violence directed against non-combatants and designed to instill fear in a target audience. It is an act that influences an audience beyond the immediate victim. Terrorism as we previously said is not a new phenomenon; it is deeply embedded in history. A peep into history records that, terrorism has been one of the starkest expressions of rejection of authority. Terrorism eats away the sociopolitical fabric of many states, undermines democracy, provides a rational for a government to delay democratic reforms and can increase tension among states. The result is often impression that the world is in a state of chaos, and international order and authority are collapsing (Viotti \& Kauppi, 2009).

We have noted that the strategy of terrorists embraces the entire gamut of activities committed violently, that draws the attention of the local populace, the government and the world to their cause. The plan of the attack is always to obtain the greatest publicity, choosing targets that symbolize what they oppose. Again, the effectiveness of the terrorist act, lies not in the act itself, but in the public's or government's reaction to the act. A terrorist does not see himself or herself as evil. He believes that he is only fighting for what he believes in by whatever means possible. Hence, the phrase, one man's terrorist is another man's freedom fighter. As we have said before, good number of variables has been advanced as the causes of terrorism. These include; psychological, social, economic, ideological, cultural, religious and environmental factors. These variables also add to the new emergent typologies of terrorism which are agro-terrorism, bioterrorism, cyber-terrorism, eco-terrorism, and narco-terrorism. The terror networks act like non-governmental organizations, de-territorial and decentralized; thus on the one hand local and on the other transnational (Ulrich, 2003). A notable example is the dreaded Al Qaeda network, led by the late Osama Bin Laden which symbolizes the new phenomenon of privatization of terrorism.

\section{International Law and the Legal Justification of War on Terror}

International law is the body of rules, which apply between states and entities that have been granted international personality. It is seen as a body of rules that have been accepted by civilized nations as being binding in their relationship with one another (Akinboye \& Ottoh, 2007: 238). International law basically evolved in tandem with the nation-state system from the Peace of Westphalia (Spiegel \& Wehling, 1999).

International Humanitarian law on the other hand is the branch of international law limiting the use of violence in armed conflicts by: (a) sparing those who do not or no longer directly participate in hostilities. (b) Limiting the violence to the amount necessary to achieve the aim of the conflict, which can be independent of the causes fought for only to weaken the potential of the enemy?This definition leads to the basic principle of International Humanitarian Law

i. The distinction between civilians and combatants;

ii. The prohibition to inflict unnecessary suffering;

iii. The principle of necessity;

iv. The prohibition to attack those hors de combat and lastly'

v. The principle of proportionality (Sassoli and Bouvier, 1999:67).

In essence the fundamentals of international law are structured cum designed to maintain global peace and security.

It is indeed a truism that terrorism, endangers innocent lives, causes losses of social wealth, jeopardizes state security and constitutes a serious challenge to human civilization and dignity as well as sorrow and threat to international peace and security (China Daily, 2001). It is, however, a more fundamental truth that just because there is no global consensus on what constitutes terrorism and who are terrorists, there is yet to be in existence, an international law that solely and in all ramifications out laws terrorism. But this does not mean that there is lack of international conventions that condemns terrorist acts. More often than not, the category or aspect of international law that is applied in the fight against terrorism is treaty law, situated in the United Nations charter. However, the provisions of Articles 2(4) and 51 are adopted as the legal framework or background in prosecuting the "war on terror".

Article (4) of the United Nations charter states inter alia, that all members (states) shall refrain in their international relations from the threat or use of force against the territorial integrity or political independence of any state, or in any manner inconsistent with the purpose of the United Nations. While Article 51, of the United Nations charter state, that : nothing in the present charter shall impair the inherent right of individual or collective self-defense if an armed attack occurs against a member of the United Nation, until the Security Council has taken measures necessary to maintain international peace and security. Measures taken by members in the exercise of this right of self-defense shall be immediately reported 
to the Security Council and shall not in any way affect the authority and responsibility of the Security Council under the present charter to take at any time, such action as it deems necessary in order to maintain or restore international peace and security.

The issues raised here are what action can be categorized as a threat or use of force against the territorial integrity or political independence of a state? And under what condition can the principle of self-defense or collective self-defense be a legally accepted option. The above issues when presented for critical analyses create difficult answers, on issues such as the war on terror.

\section{Critical Issues in the Legal Justification of the War on Terror}

It is quite glaring that some critical issues have enveloped the prosecution of the "war on terror". One of such contending issues has to do with the phrase "war on terror". The notion "war against terrorism" has proven highly contentions with critics charging that it has been exploited by most participating governments to pursue their longstanding policy objectives, reduce civil liberties, and infringe upon human rights (Hobsbawn, 2008). Others argue that the term "war" is not appropriate in this context since it is different from say, the war on drugs. In the absence of a tangible enemy, it is very unlikely that international terrorism could be brought to an end by means of war. The idea is that, "terrorism" is not an enemy but a tactic. To call it a war, obscures the differences between conflicting situations (Security Dialogue, 2003). A good example is the difference between the Antioccupation insurgents in Iraq and Afghanistan, and the international jihadist's in Sudan and Somalia. They have different goals and tactics. George Bush, The former president of the United States, articulating the goals of the "war on terrorism" in a September 20, 2001 speech, said that terrorism will not end until every terrorist group of global reach has been found, stopped and defeated". This of course is very far fetched.

Be that as it may, the phrase "war on terror", has been referred to as a false metaphor. According to George Lake of the Rock Ridge Institute, there cannot be a war on terror literally because terror is an abstract noun. Terror he held, cannot be destroyed by weapons or signing peace treaties. The reason is that war on terror has no end. Most writers define terrorism as the use of threat or serious violence to advance some kind of "cause". Some of these writers do state clearly the kinds of group (sub-national, non-state) or cause (political, ideological, religious) to which they refer. Others merely rely on the instinct of many people who are confronted with an act that involves innocent civilians being killed or maimed by men armed with explosives, firearms or other weapons. None of these references is satisfactory, and so grave problems with the use of the term persist. Terrorism is after all, a tactic. The term "war on terrorism", may not be acceptable as meaning a war on tactics.

It is further disputed that the "war on terrorism" does not qualify as war, since there is no party whose defeat can bring victory. Ken McDonald, Director of The Public Prosecution and Head of the Crown Prosecution Service in the United Kingdom, was said to have stated that, those responsible for acts of terrorism such as the 7, July, 2005 London bombings are not "soldiers" in a war, but "inadequate" who should be dealt with by the criminal justice system. To him, the response to terrorism had to be proportionate and grounded in due process and the rule of war. London is not a battle field and those innocents who were murdered are not victims of war. Those who killed them were not soldiers. They are deluded, narcissistic inadequate (Nicholas, 2008). The fight against terrorism on the streets of Britain is not a war. It is the prevention of crime, the enforcement of our laws, and the winning of justice for those damaged by it. What one can rightly deduce from the above postulations is that, there cannot be a war on terrorism. Terrorism is a natural, unpredictable orientation whose output breeds violence.

\section{Global and tactical Response to Terrorism}

The major proponent of the war on terror is the United States of America and her coalition allies. This is borne out by current events in Iraq, Libya and Afghanistan. Iraq was under the leadership of the late President Saddam Hussein when the invaded by American forces under the accusation that Iraq was producing and piling weapons of mass destruction, which represented a threat to world peace and security. It was also alleged that, Iraq had links with Osama Bin Ladin's Al Qaeda terrorist group which master-minded the bombing of the twin towers of the American World Trade Centre in September 11, 2001. The justification offered for the invasion of Iraq at the time was to prevent terrorism or future attack by the Iraqi government sponsored terrorists against the United States of America, her allies and other nations of the world. The United States of America claimed that the invasion of Iraq was carried out in line with Article 51, of the United Nations Charter, which deals with the principle of self-defense. Consequently, the United States Congress in a joint resolution noted that, the 9/11 attack renders it both necessary and appropriate that the United States exercise its rights to self-defense and to protect United States citizens, both at home and abroad and 
to prevent acts of international terrorism against the United States".

As one of the crucial factors militating against the enforcement of international law, the issue is that powerful states like the United States of America, more often than not, interprets international law to suit their actions and policies. These allegations later turned out to be false, rendering the invasion of Iraq unjustifiable. The reason is that, there was no substantive evidence about the allegations. The opponents of the war are of the opinion that, the invasion of Iraq failed to fulfill the requirements of a just war and that Iraq Sovereignty was undermined by the United States and her coalition partners.

The fact is that, Article 33 of the United Nation's charter states that "the parties to any dispute, the continuance of which is likely to endanger the maintenance of international peace and security, shall first of all seek a solution by negotiation, enquiry, mediation, conciliation, judicial settlement, resort to regional agencies or arrangements, or other peaceful means of their own choice". The United States failed to explore all these avenues for peaceful settlement of disputes before invading Iraq. Further more, Resolution 441 of the United Nations on which the United States of America hinged on, did not authorize war. It only called on Iraq to "allow unfettered access by Iraq to U.N weapon inspectors' which Saddam complied with. The United States of America and her partners could not wait for the outcome of the weapon inspectors report, before invading Iraq.

The report of the weapon inspectors (which was released after the American invasion of Iraq) shocked the world when the United Nation chief weapons inspector Hans Blix and Mohamed El Baradei, in charge of Nuclear Arms inspection concluded that "Iraq does not have weapons of mass destructions". The independent 1,000 strong team (Iraq survey group) sent by Washington to look for weapons of mass destruction in Iraq also concluded that, they found nothing in Iraq, and that Saddan Husseins Iraq has no link with Al Qaeda and the 9/11 attacks. The war, therefore, was fought under falsehood. The use of force and the requirement of proportionality was not adhered to in this instance which constitutes a serious violation of international law, especially Articles 2 (3) and 2(4) of the United Nations Charter. From these facts we cannot accept the invasion of Iraq as an action or war against terrorism.

Classical international law deals with two generic situations: War and peace. There is a big rule-book dealing with the laws of warfare, the law of how to open war, and how to end war, what weapons to be used, and how to treat captives. Different rules apply to countries when there is peace and when there is war. In peace time, people are divided into two categories. They are either law-abiding citizens or criminals to be dealt with by the police and courts. In a war time, people are divided into two different categories civilians or combatants (Reisner, 2002:7). The question therefore is, how does the United States and her allies classify combatants and civilians in a war and peace situations? Do they also abide by the rules of war/ The Bush Administration it seems literalized its war on terrorism by dissolving the legal boundaries between what a government can do in peace time and what is allowed in war time. This move according to Ruth may have made it easier for Washington to detain or kill suspects, but it has also threatened basic due process rights, thereby endangering us all (Roth, 2004).

The singular act of branding terrorist suspects as enemy combatants constitutes an illegality. It negates the legal principle of being innocent until proven otherwise. Consider for example, the case of Dose Padilla and Ali Saleh Kahlah al-Mari, United States Federal officials arrested Padilla in May 2002, when he arrived from Pakistan at Chicago's O'Hare Airport, alleging that he came to scout out target for a radiological (dirty) bomb. As for Al-Mari, a student from Qatar, he was arrested in December 2001 at his home in IIlinois for allegedly being a "sleeper" agent: an inactive terrorist who, once activated, would help others launch attacks. President Bush, invoking war rules, declared both men to be "enemy combatants" allowing the United States government to hold them without charge or trial as long as possible (Roth, 2004).

The Geneva Convention and the Nuremberg principles clearly state how prisoners of war and civilians are to be treated during the period of war and what constitutes a war crime. The extraJudicial detention and unwarranted abuse and torture of prisoners at Guantanamo Bay in Cuba and the Abu Ghraid prison in Iraq, coupled with the activities of CIA secret detention facilities located in different parts of the globe, clearly violate the laws of war. At the Abu Ghraid in Iraq for instance, prisoners were subjected to different kinds of torture and were even highly dehumanized by being paraded naked and mocked by American Soldiers (Laqueur, 2006).

The fourth Geneva Convention lay emphasis on the protection of civilian persons in term of war. But the manifestation of the war on terror saw the 'collateral' targeting of civilian populations and the destruction of lives and property. Logically, the staggering proportion of civilian casualties witnessed so far in the war of terror clearly out weighs the so called threat posed by the terrorists. The bombing of electricity and water plants and even hospitals are issues of reference. Indeed laws are silent among (those who use) weapons as opined by Cicero (Dunlap, 2002). 
The Global fact remains that the war on terror has only succeeded in breeding more terrorists. Terrorism is an ideology, and people will continue to subscribe to it. The disaster in Iraq war has presented unimaginable gifts to the terrorist cause. The decision to invade Iraq reinforced Al-Qaeda accusation of western interference in Moslem territories while the abuse of prisoners at the $\mathrm{Abu}$ Ghraib prison, undermined western claims to moral superiority.

Western actions in Iraq, Libya and Afghanistan seem to have exposed the abuses inherent in the application of the principle of self-help or self preservation in international law, The action also illustrate the difficulties involved in the application of the principle of "reasonableness" in reprisal measures, a principle which demands that attack should be aimed at the destruction of camps or bases of the guerrillas or terrorists without injury to the territorial state (Agwu, 2005).

With the politicization of the veto system in the United Nations Security Council, international law is like a bleeding mother, watching the killing of her children while the war on terrorism is continues. The difficulty in resolving the issue of categorizing terrorism, terrorist, and terrorist action, the have continued to militate against global Consensus of a concept that is very vital for the attainment of global peace and security.

Other critics are of the opinion that the war on terror has a double standard connotation. The American government has granted political asylum to several terrorists and terrorist organizations that attack Cuba in an attempt to over throw the Castro regime while the American government claims to be anti-terrorist. It is even sad to note that the alleged mastermind behind the 9/11 attacks was part of the Mujadin who were sponsored, aimed trained and aided by the CIA to commit terrorist acts in Afghanistan to fight the Russia army after it invaded Afghanistan. Majority of the terrorists that executed the 9/11 attack in the United States were said to be of Saudi Arabian origin. However, Saudi Arabia has escaped reprisal attack and has remained an American staunch ally.

\section{Conclusion}

Although, the war on terror was initially conducted by the United States and her allies for their defense, terrorist attacks have expanded and have now engulfed the third world countries. In fact, terrorism is now global. Instead of abating, it is increasing. Global opinion is now seriously divided between those who favour military action and those who do not. Other differing opinions hold that the process of fighting the war has led to the commission of possible war crimes and has stretched to war against humanity.
As Nicholas (2008) observed, the only way for preventive action to gain international legitimacy is for it to be blessed by the United Nations, but this does not seem to be the case. Preventive war has never had a good name as exemplified by events in Iraq and Afghanistan. Once powerful states start taking the war into their own hands, even for the best of motives, there is no telling where they will stop and the repercussion that will follow.

The war against terror as we have said is not only costly to the nations at the receiving end but also to the prosecuting nations. For instance, United States needs 6 billion dollars only to dismantle and carry home its war machines from Afghanistan. This adds to the economic difficulties the United State is faced with. For the receiving states, there is no light at the end of the tunnels. Their economy and infrastructure are all ruined and population decimated.

This paper is of the view that in the absence of a clear cut definition of terrorism, war on terror in the form of military adventure should not be seen as the best option in securing international peace and stability. Approaches based on constraint and United Nations approved economic embargo and other diplomatic sanctions as currently applied to Iran and North Korea may in the long time, produce a better option for the control of perceived and state sponsored terrorism. We have to remember that violence breeds more violence.

\section{References}

Akinboye, A \& Ottoh, S (2007). International Relations, Malthus Press, Lagos.

Awgu, F. (2005). United Nations System, State Practice and the Jurisprudence of the Use of Force Lagos, Malthouse Press Limited, Lagos

Riedel, B (2008). The Search for Al Qaeda, its Leadership, Ideology and Future, Booking Institute Press. London.

Downes, A. (2008). Targeting Civilians in War, Cornell University Press

Doyle, M (2008). Striking First: Preemption and Prevention in International Conflict, Princeton University Press.

Dunlap, D (2002). International law and terrorism: Some questions and answer for operations, Rigworth Press, Oslo.

Enodien, T. (2003). Impending Demise of the United Nation, the Guardian, Sunday 27, April.

Eze, I. (2003). Kofi Annan slams United States over Iraq, Vanguard, Wednesday, September 24.

Hobsbawn, E (2008). On Empire: America, War and Global Supremacy, Pantheon, Books, Chicago.

Kegley, C (2007). World Politics: Trend and Transformation, Eleventh Edition, Thomson Wadsworth.

Laqueur, W (2006). The Terrorist to Come in Thomas Badey (eds), Violence and Terrorism 06/7, McGraw Hill, Iowa

Laqueur, (1999). The New Terrorism: Fanatism and the Arms of Mass Destruction, Oxford University Press New York

Mingst, K (1999) Essentials of International Relations, W.W. Norton and Company, Inc, London

Mukwaya, A (2004) The Politics of International Terrorism, African Journal International Affairs, 7 (1, 2), p.34.

Nicholas, T (2008). Eve of Destruction: The coming age of Preventive war, University of Pennsylvania Press. 
Reisner, D (2002) The Evolution of International Law and the war on terrorism, Jerusalem Issue, Brief 2(14), December 24.

Roth, K (2004). The Law of War in the War on Terror, Foreign Affairs. January/February

Security Dialogue (2003). Is the United States of America fighting Terrorism with the Wrong Weapon? 34(1) March, Sage Publications, P.121-122.

Shaw, M (1998). International Law, $4^{\text {th }}$ Edition, Cambridge University Press Cambridge

The Charter of the United Nations (n.d) Retrieved from: http://www.un.org/

ThisDay News (2003). Iraq has no weapons of Mass Destruction-UN Inspectors. 15 February
Toros, H (2008). Legitimacy and Complexity on Terrorist Conflicts, Security Dialogue, 39(4) August.

Tylor., P (2009). A World of Troubles; The White House and the Middle-East from the Cold War to the War on Terror, Straus and Giroux.

United States of America (2001). The Silence of Words: on Terror and War, Security Dialogue 34(3) September

Viotti, P. \& Kauppi M. (2009). International Relations and World Politics. Security, Economy and Entity, $4^{\text {th }}$ Edition, Pearson Educational Inc. New Jersey.

Wardlaw, G (1989). Political Terrorism: Theory, Factors and Counter-measures, Cambridge University Press.

Wedgwood, R \& Kenneth, R (2009). Combatants or Criminals? How Washington should Handle Terrorists, Foreign Affairs, January/February. 